\title{
Evolution of Forest Pedogenesis in the South of the Forest-Steppe of the Central Russian Upland in the Late Holocene
}

\author{
Yu. G. Chendev ${ }^{a, *}$, A. L. Aleksandrovskii ${ }^{b}$, O. S. Khokhlovac ${ }^{c}$ M. I. Dergacheva ${ }^{d}$, A. N. Petin ${ }^{a}$, \\ A. N. Golotvin ${ }^{e}$, V. A. Sarapulkin ${ }^{a}$, G. L. Zemtsov ${ }^{f}$, and S. V. Uvarkin ${ }^{e}$ \\ ${ }^{a}$ Belgorod National Research University, ul. Pobedy 85, Belgorod, 308015 Russia \\ ${ }^{b}$ Institute of Geography, Russian Academy of Sciences, per. Staromonetnyi 29, Moscow, 119017 Russia \\ ${ }^{c}$ Institute of Physicochemical and Biological Problems of Soil Sciences, \\ ul. Institutskaya 2, Pushchino, Moscow oblast, 142290 Russia \\ ${ }^{d}$ Institute of Soil Science and Agricultural Chemistry, Siberian Branch of the Russian Academy of Sciences, \\ ul. Sovetskaya 18, Novosibirsk, 630099 Russia \\ eScientific and Production Association “Chernozem'e”, ul. Moskovskaya 101a, Lipetsk, 398042 Russia \\ ${ }^{f}$ Lipetsk State Pedagogical University, ul. Lenina 42, Lipetsk, 398914 Russia \\ *e-mail sciences@mail.ru \\ Received November 18, 2015
}

\begin{abstract}
The Late Holocene stage of forest pedogenesis has been studied on the interfluves along river valleys in the forest-steppe zone of the Central Russian Upland. The development of gray forest soils from the former chernozems as a result of the Late Holocene advance of forest vegetation over steppes is discussed. It is argued that the climatic conditions of the Subatlantic period were unstable, so that multiple alternation of forest and steppe vegetation communities took place. This specified a complex character of soil evolution upon contrasting substitution of forest pedogenesis for steppe pedogenesis. On the interfluves near the natural drainage network (balkas, ravines, and steep slopes of river valleys), the climate-driven dynamics of forest and steppe vegetation with corresponding changes in the character of pedogenesis could take place during the entire Holocene, which is reflected in a lower thickness of humus profiles and deeper leaching of carbonates from chernozems of the Early Iron Age in comparison with their analogues formed under steppe cenoses in central parts of the interfluves. Two variants of the evolution of gray forest soils can be suggested: the pulsating evolution typical of balkas and interfluves near river valleys and the continuous progressive evolution typical of automorphic (plakor) positions in central parts of the interfluves.
\end{abstract}

Keywords: chernozems (Chernozems), gray forest soils (Albic Luvisols), forest-steppe, Central Russian Upland, interfluves, drainage network, soil evolution, Holocene

DOI: $10.1134 / \mathrm{S} 1064229317010033$

\section{INTRODUCTION}

Many studies are devoted to the genesis and evolution of gray forest soils in the East European foreststeppe $[1,2,4,5,7-10,17,18,21,23,27,28,30,35$, $36]$. In the course of long-term discussions, several different opinions on the genesis, age, and evolution of these soils have been shaped. A hypothesis about the development of automorphic gray forest soils in the forest-steppe zone from chernozems as a result of the advance of forest vegetation over former steppes is supported by data on the presence of relict features of steppe pedogenesis in the profiles of gray forest soils. In particular, these are paleotunnels of steppe mole-rats and second humus horizons representing the remains of the lower part of deep humus horizons of paleochernozems of the Middle Holocene age [4, 10, 17]. The secondary character of forest vegetation and forest soils as zonal components of forest-steppe landscapes is also proved by the occurrence of chernozemic soils along the periphery of forest massifs that advanced over steppe areas in the recent past [7, 21]. Later, additional arguments in favor of this hypothesis were found during comparative studies of the soils buried under earthy ramparts in this zone; such soils bear clear features of steppe pedogenesis. Their modern analogues can be found in some areas under forest groves in the foreststeppe zone [2, 36].

An opposite hypothesis suggests that forest-steppe ecosystems have developed in place of zonal forest ecosystems under the impact of anthropogenic deforestation and the increasing role of herbs in forest pedogenesis. This hypothesis considers gray forest soils as a result of the evolution of podzolic soils into gray forest soils with deeper humus horizons or even 
(a)
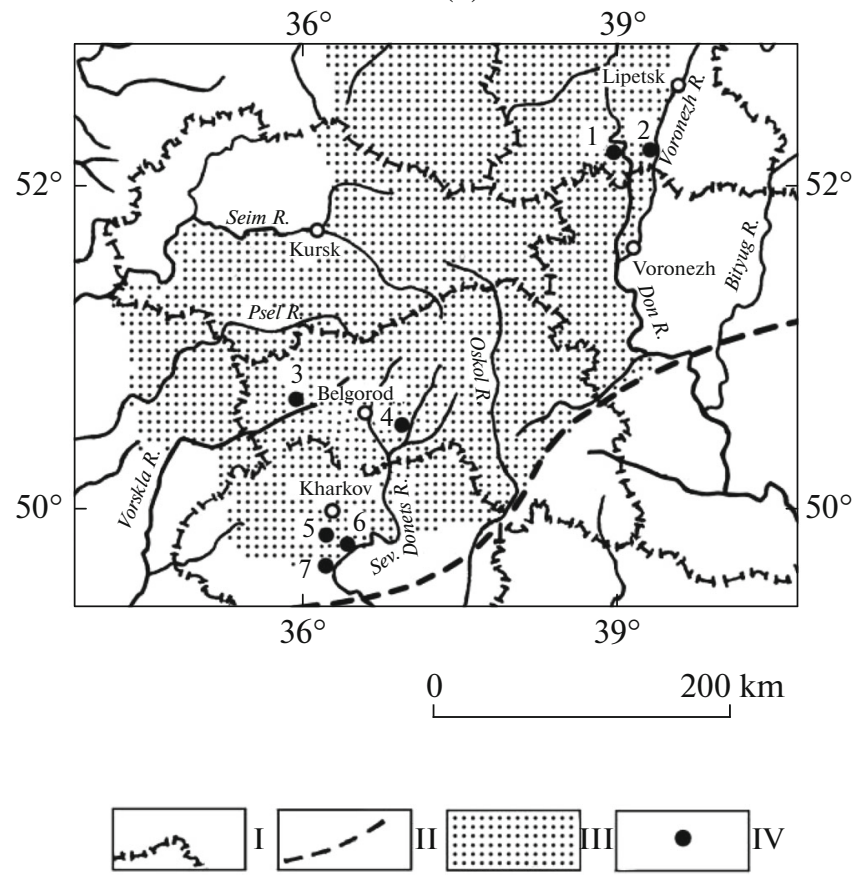

(b)
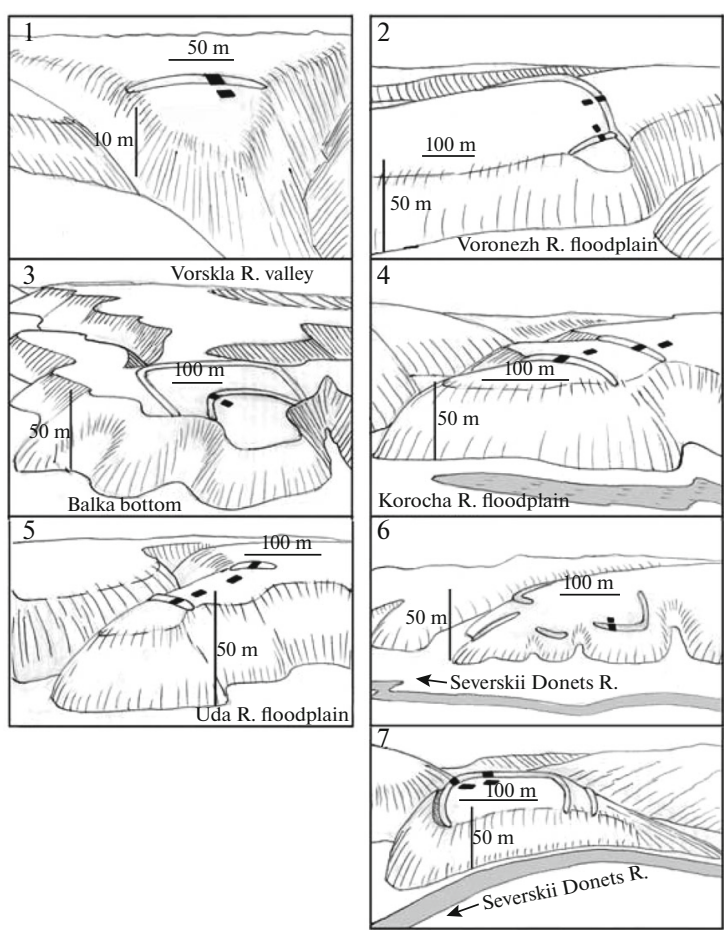

Fig. 1. The location of studied settlements (a) and their position in the local mesorelief with indication of the position of earthy ramparts (lines) and places of soil studies (black zones) (b). Conventional signs on scheme (a): I-administrative boundaries, II-foreststeppe/steppe boundary, III-forest-steppe of the Central Russian Upland, and (IV) location of ancient settlements. Settlements: (1) Mukhino, (2) Podgornoe, (3) Borisovka, (4) Dmitrievka, (5) Vodyanoe), (6) Mokhnach, and (7) Korobovy Khutora.

into chernozemic soils under meadow vegetation in place of former forests [30, 32].

There is also an opinion about the independent selfsustained nature of forest-steppe landscapes and gray forest-steppe soils of the Holocene age [7, 8, 19, 20]. This opinion is supported by a new theory of the origin of second humus horizons as the horizons typical of forest pedogenesis [22] and by the substantiation of the possibility of the development of some chernozemic soils under forest vegetation [6].

The studies performed by our team were also devoted to the genesis and evolution of gray forest soils in the east European forest-steppe. Several new archaeological sites were examined in the foreststeppe zone within the southern part of the Central Russian Upland. We studied chronosequences of buried and modern surface soils in the areas of ancient settlements located in the peripheral parts of interfluves near river valleys and balkas (flat-bottomed ravines) with the use of a set of methods in order to obtain new knowledge about different variants of the evolution of forest-steppe soils in the Holocene.

\section{OBJECTS AND METODS}

Ancient settlements are unique objects of cultural heritage in the forest-steppe zone of the East European Plain. They appeared in the Scythian epoch and ended their functioning in the medieval epoch. For pedologists, these objects retain valuable paleoenvironmental information in the soils buried under earthy ramparts that surrounded the settlements as defense lines. In this paper, we consider the results obtained during the study of seven ancient settlements in the central and southern parts of the forest-steppe zone on the Central Russian Upland (Fig. 1). From the north to the south, these are the Mukhino and Podgornoe settlements in Lipetsk oblast; the Borisovka and Dmitrievka settlements in Belgorod oblast; and the Vodyanoe, Mokhnach and Korobovy Khutora settlements in Kharkov oblast. The names to these ancient settlements were given according to the names of nearly located modern settlements. Field studies of these objects were performed by archaeologists together with pedologists. In different years, the archaeological works were headed by A.N. Bessudnov, A.P. Medvedev, V.V. Koloda, V.A. Sarapulkina, A.N. Golotvin, and G.L. Zemtsov. In the discussion of the results of our studies, we also used published data on a number of other archaeological sites: the Verkhnee Kazach'e ancient settlement near the Mukhino settlement in Lipetsk oblast [34] and several ancient settlements in the northern part of the forest-steppe zone in Kursk and Lipetsk oblasts [3, 29]. 
Table 1. Some physiographic characteristics of studied sites

\begin{tabular}{l|c|l|c|c|c|c}
\hline \multicolumn{1}{c|}{ Settlement } & $\begin{array}{c}\text { Absolute } \\
\text { height, } \mathrm{m}\end{array}$ & Parent material & Soil texture & $\begin{array}{c}\text { Mean annual } \\
\text { air temperature, } \\
{ }^{\circ} \mathrm{C}\end{array}$ & $\begin{array}{c}\text { Mean annual } \\
\text { precipitation, } \\
\mathrm{mm}\end{array}$ & $\begin{array}{c}\text { Hydrothermic } \\
\text { coefficient, } \\
\text { May-Sept. }\end{array}$ \\
\hline Mukhino & 165 & LSL & $\mathrm{sl}$ & +5.3 & 510 & 1.10 \\
Podgornoe & 145 & MSL/LS-S & $\mathrm{sl}$ & +5.3 & 520 & 1.09 \\
Borisovka & 190 & LSL & $\mathrm{sl}$ & +6.3 & 610 & 1.15 \\
Dmitrievka & 170 & MSAL/LS-S & $\mathrm{sl}$ & +6.7 & 580 & 1.10 \\
Vodyanoe & 130 & MSAL/LS-S & $\mathrm{sal}$ & +7.5 & 530 & 1.05 \\
Mokhnach & 125 & LSL & $\mathrm{sl}$ & +7.5 & 540 & 1.04 \\
Korobovy & 155 & MSL/LS-S & $\mathrm{sl}$ & +7.6 & 520 & 1.02 \\
Khutora & & & & & & \\
\hline
\end{tabular}

Parent materials: LSL-loesslike silt loam, MSL/LS-S-mantle silt loam underlain by ancient alluvial loamy sand and sand; MSAL/LS-S—mantle sand loam (sand loam) underlain by ancient alluvial loamy sand and sand. Soil texture: sl—silt loam, sal-sand loam.

The studied settlements have certain similarities in the environmental factors and in their ages.

Similarities in the environmental factors concern the stratigraphy of parent materials, geomorphic position, and the character of vegetation.

All these settlements are found on elevated plateaulike interfluves near the contact with steep slopes of river valleys or deep balkas. Relatively thin $(1-1.5 \mathrm{~m})$ loesslike loams underlain by the ancient (NeogeneEarly Quaternary) alluvial sands serve as parent materials $[11,24]$. This kind of sediment sequence was found at the Podgornoe, Dmitrievka, Vodyanoe, and Korobovy Khutora settlements. Other settlements (Mukhino, Borisovka, and Mokhnach) are found in the areas with a deeper thickness $(>1.5 \mathrm{~m})$ of covering loesslike loams underlain by ancient alluvial sands. On the slopes of adjacent valleys and balkas, loesslike loams thin out exposing ancient alluvial sands that serve as parent materials. In the topography, all the studied settlements occupy cape-shaped promontories bordering steep slopes of river valleys and balkas (Fig. 1). Relative elevations of the settlements above the local bases of erosion (the surfaces of floodplains or balka bottoms) vary from $25 \mathrm{~m}$ (Mokhnach) to $50 \mathrm{~m}$ (Dmitrievka and Podgornoe).

Modern soils in the area of ancient settlements are represented by the type of gray forest soils. In the south (in Kharkov oblast), only the subtype of dark gray forest soils is present. To the north (Borisovka and Podgornoe settlements), both dark gray forest and gray forest soil subtypes can be found; further to the north (Dmitrievka and Mukhino), the subtype of gray forest soils predominates in the soil cover.

At present, the surface of ancient settlements is under oak broadleaved forests typical of forest-steppe landscapes in the center of eastern Europe.

Data on the major physiographic characteristics of natural landscapes at the studied sites are given in Table 1.
These settlements appeared in the Early Iron Age, or, according to the natural periodization of the Holocene, in the first quarter of the Subatlantic period. Radiocarbon dating of charcoal found in the bodies of ramparts gave the following results (noncalibrated age): the Mukhino site, $2170 \pm 90$ yrs. (IGRAN, no. 4159); the Podgornoe site, $2030 \pm 50$ yrs. (Kiev Radiocarbon Laboratory, Ki-19107); the Borisovka site, $2450 \pm$ 40 yrs. (Ki-18174). According to the archaeological dating of artifacts found at other sites, the ramparts of the Dmitrovka settlement were constructed 28002600 years ago; the ramparts of the Vodyanoe settlement, 2450-2400 years ago; the ramparts of the Mokhnach settlement, 2300 years ago; and the ramparts of the Korobovy Khutora settlement, 24502400 years ago. Some of the ramparts around the settlements were constructed later. Thus, the second rampart of the Podgornoe settlement contained charcoal with the radiocarbon age of $1150 \pm 110$ yrs. (Ki19108). After the Scythian time, the Dmitrievka and Mokhnach settlements were occupied by representatives of the Saltovo-Mayatskay culture in the middle of the 8th century AD. The age of ramparts constructed by them (directly on the ramparts of the Scythian time or near them) is determined at about 1250 years (according to archaeological data). The inner earthy rampart around the Vodyanoe settlement was constructed by representatives of the Romenskaya culture; its age is estimated by archaeologists at about $1150-1050$ years.

At all the sites, buried paleosols are well preserved under the ramparts of the Early Iron Age and the Early Medieval epoch. Their profiles were analyzed in order to reconstruct the history of pedogenesis and the paleoenvironmental conditions. It should be noted that the studied buried paleosols were well isolated from the impact of recent pedogenesis by earthy ramparts of considerable $(0.8-1.8 \mathrm{~m})$ thickness. Paleosol and paleoenvironmental reconstructions were based 
on the comparative analysis of the properties of buried paleosols of different ages and their modern surface analogues that continued their development near the ramparts under similar geomorphic conditions (level or slightly inclined $\left(<2^{\circ}\right)$ interfluve surfaces near steep slopes of river valleys and balkas).

Our study was based on the genetic analysis of the soil profiles with identification of the particular characteristics of the polygenetic nature of the studied soils [31].

The method of soil chronosequences suggested by Gennadiev $[12,13]$ is widely applied by Russian pedologists and archaeologists [14, 15, 33, 35]. This method is based on the comparative study of soils buried under earthy archaeological monuments (kurgans, ramparts, and cultural layers of ancient settlements) and natural surface soils of the background landscapes near the archaeological sites. The soil burying under an artificial substrate of considerable thickness means that the soil becomes isolated from the sphere of active pedogenesis and retains its properties corresponding to the combination of environmental factors before the soil burying in a relatively stable state for a long time (centuries and millennia). Thus, a comparison of the properties of buried paleosols with the properties of background surface soils that continued their normal development up to the present day makes it possible to judge the direction and rate of the soil evolution. The more ramparts of different ages with the soils buried under them are available for the study, the more detailed information on temporal changes in the environment can be obtained from comparison of the components of the soil chronosequence. This method was the major method to study the soils of ancient settlements. Other methods included the comparative geographic analysis, laboratory methods of soil analyses, absolute dating of the ramparts by the radiocarbon method (in the radiocarbon laboratories in Kiev and in the Institute of Geography in Moscow), and the archaeological dating of the objects.

\section{RESULTS AND DISCUSSION}

Our study showed the presence of dark-humus soils with some features of the Middle-Holocene steppe pedogenesis under the ramparts constructed in the first quarter of the Subatlantic period (28002030 years ago) on the interfluves near the slopes of river valleys and balkas. These soils can be classified either as chernozems without morphologically expressed features of forest pedogenesis (Mokhnach and Borisovka sites), or as chernozems subjected to the initial stages of degradation under forest vegetation manifested by angular blocky structure of the buried [B] horizon with glossy illuviation coatings on ped faces (Korobovy Khutora, Vodyanoe, Dmitrievka, and Podgornoe sites). At the Mukhino settlement located on a plateau-like interfluve between upper branches of a large balka, the soil buried under the rampart was identified as a typical dark gray forest soil. At other settlements of the Scythian time in the northern part of the Central Russian Upland, the soils buried under ramparts were also identified as dark gray forest soils; in particular, they were described near the Don River valley in Lipetsk oblast [34], at the Pereverzevo-1 site in Kursk oblast [29], and at several ancient settlements in the central and northern parts of Lipetsk oblast $[2,3]$. Thus, we can suppose that the stage of afforestation and forest pedogenesis in the northern part of the modern forest-steppe zone took place earlier than in the southern part of this zone, which is reflected in the development of gray forest soils at the beginning of the Subatlantic period of the Holocene.

The modern background analogues of the paleosols of the Early Iron Age at all the sites are represented by gray forest soils that have developed under the impact of long-term forest pedogenesis. The soils under ramparts created in the Early Medieval period (the 8th-9th centuries AD) were studied at the Mokhnach, Vodyanoe, Dmitrievka, and Podgornoe sites. They reflect a fairly long stage of forest pedogenesis on the interfluves. They were identified as podzolized chernozems, or as intergrades between chernozems and gray forest soils. |In the northern part of the studied region (Podgornoe site), they were identified as dark gray forest soils developed from chernozems. Data on the classification position of studied soils of the ancient settlements and the morphology of their profiles are summarized in Tables 2 and 3.

A general regularity of the natural evolution of soils on peripheral parts of the interfluves in the southern part of the forest-steppe zone of the Central Russian Upland in the past 2800 years is the transition from the stage of steppe pedogenesis to the stage of forest pedogenesis accompanied by the transformation of chernozems into gray forest soils with podzolized chernozems as the transitional state of the soils. This general evolutionary pattern is illustrated by the examples of soil chronosequences studied at the sites of Mokhnach in Kharkov oblast and Podgornoe in Lipetsk oblast (Fig. 2).

As follows from the analysis of Fig. 2, in the northern part of the region with colder climatic conditions, the transformation of chernozems into gray forest soils proceeded with higher rates. In the south of the foreststeppe zone, the evolutionary changes proceeded slower and were less contrasting.

At the same time, this trend of transformation of chernozems into gray forest soils on the sites occupied by forests in the Late Holocene was disturbed by the opposite processes of the return of steppe vegetation on the watersheds (steppezation) and the retreat of forests into the erosional depressions; the development of steppe vegetation on the interfluves was accompanied by the progradation of forest soils into steppe chernozems. 
Table 2. Classification position of soils in the studied chronosequences (forest-steppe zone of the Central Russian Upland)

\begin{tabular}{l|l|l|c}
\hline \multirow{2}{*}{ Settlement } & \multicolumn{2}{|c|}{ Buried paleosols } & \multirow{2}{*}{ Background surface soil } \\
\cline { 2 - 3 } & \multicolumn{1}{|c}{ 8th-1st centuries BC } & 8th-11th centuries AD & \\
\hline Mukhino & DGF & None & GF \\
Podgornoe & $\mathrm{CH}^{1}$ from $\mathrm{CH}^{\mathrm{p}}$ & DGF from $\mathrm{CH}^{\mathrm{p}}$ & DGF \\
Borisovka & $\mathrm{CH}^{\mathrm{t}}$ & None & DGF \\
Dmitrievka & $\mathrm{CH}^{1}$ & DGF from CH & GF \\
Vodyanoe & $\mathrm{CH}^{\mathrm{t}}$ from $\mathrm{CH}^{\mathrm{p}}$ & $\mathrm{CH}^{\mathrm{p}}-\mathrm{DGF}$ & DGF \\
Mokhnach & $\mathrm{CH}^{1}$ & $\mathrm{CH}$ & DGF \\
Korobovy Khutora & $\mathrm{CH}^{\mathrm{p}}$ & None & DGF \\
\hline
\end{tabular}

Soils: DG-gray forest, DGF-dark gray forest, DGF from $\mathrm{CH}^{\mathrm{p}}$-dark gray forest developed from podzolized chernozem, $\mathrm{CH}^{\mathrm{p}}-$ podzolized chernozem, $\mathrm{CH}^{\mathrm{p}}-\mathrm{GF}$ - podzolized chernozem transitional to dark gray forest, $\mathrm{CH}^{\mathrm{l}}$ from $\mathrm{CH}^{\mathrm{p}}-$ leached chernozem developed from podzolized chernozem, $\mathrm{CH}^{\mathrm{l}}$-leached chernozem, $\mathrm{CH}^{\mathrm{t}}$ from $\mathrm{CH}^{\mathrm{p}}$-typical chernozem developed from podzolized chernozem, $\mathrm{CH}^{\mathrm{t}}$-typical chernozem.

One of such episodes took place during the ScythianSarmatian epoch (5th century BC-3rd century AD) [5, 36]. The features left in the soils by this recurrent evolution were studied at the Vodyanoe, Mukhino, Podgornoe, and Verkhnee Kazachie settlements that appeared 2400-2000 years ago.

The results of soil studies at the Vodyanoe and Mukhino sites can serve as an example of the recurrent steppe pedogenesis against the background evolution of steppe chernozems into gray forest soils.

The Vodyanoe site is found on the right-bank part of the Uda River valley at the contact between steep slopes of the valley and the plateau-like interfluve in Zmievsk district of Kharkov oblast. It occupies the summit of a promontory bordered by the steep slope of the Uda valley from the north and by the steep slope of the balka opened to the Uda River (Fig. 1).
The settlement has two defense lines constructed in different times and consisting of earthy ramparts and ditches in front of them. The most ancient defense line was built during the Scythian period, 2450-2400 years ago. On the rampart, an underdeveloped gray forest soil has formed. It has the following horizonation: A1 $(0-20 \mathrm{~cm})-A 1 A 2 B(20-38 \mathrm{~cm})-A 2 B(38-55 \mathrm{~cm})-$ $\mathrm{BC}(55-80 \mathrm{~cm})$. The carbonates are absent in this surface soil. The soil buried under this rampart has been identified as a typical chernozem developed from a podzolized chernozem. This means that at the time of the rampart construction, the territory around the settlement was under herbaceous steppe vegetation, under which the development of typical chernozems took place. However, in the earlier period, this territory was covered by the broadleaved forest, under which the podzolized chernozem was formed. The
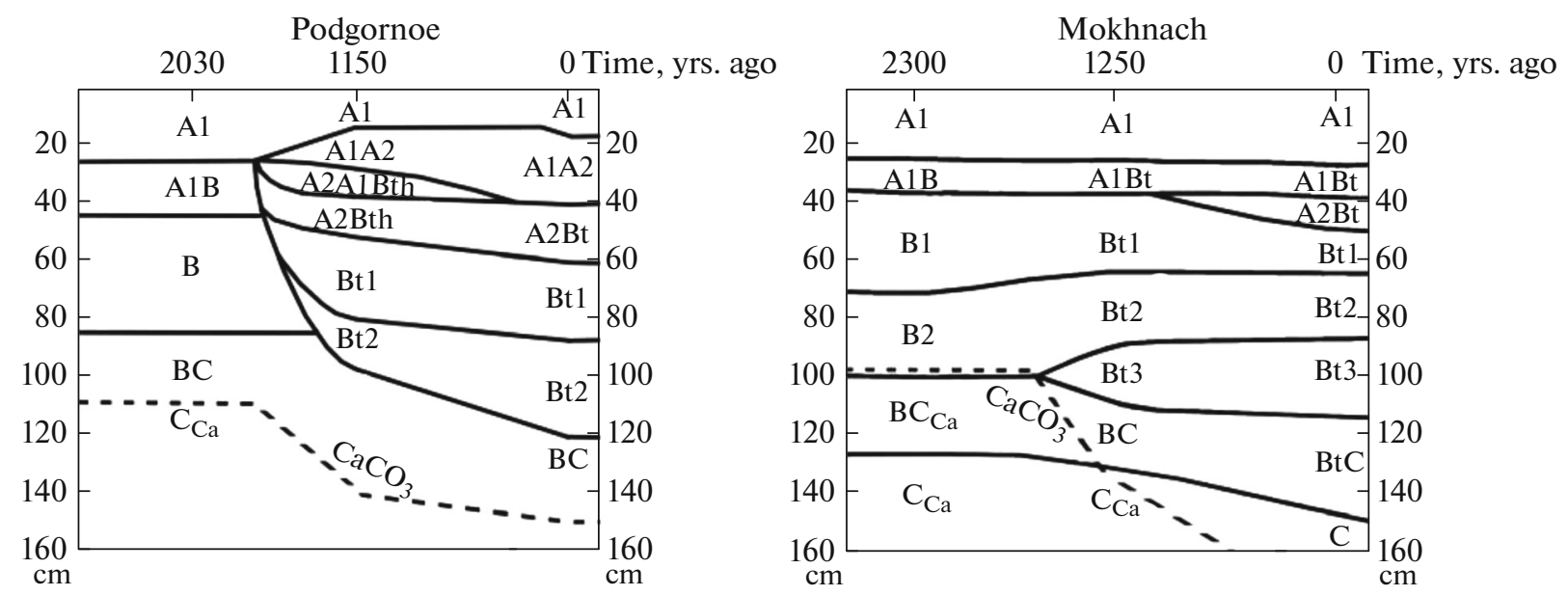

Fig. 2. Soil chronosequences reflecting the evolution of silty loamy chernozems into gray forest soils in the central (site Podgornoe, $150 \mathrm{~km}$ from the boundary with the steppe zone, left plot) and southern (site Mokhnach, $30 \mathrm{~km}$ from the boundary with the steppe zone, right plot) parts of the forest-steppe zone of the Central Russian Upland. Dashed line shows the boundary of effervescence. 
Table 3. Horizonation of the buried and background surface soils studied at ancient settlements

\begin{tabular}{|c|c|c|}
\hline \multicolumn{3}{|c|}{ Symbols of soil horizons, characteristics depth intervals, and the depth of effervescence, $\mathrm{cm}$} \\
\hline \multicolumn{3}{|c|}{ Mukhino } \\
\hline $2170 \pm 90$ yrs. ago & - & Modern period \\
\hline$[\mathrm{A} 1], 0-22$ & - & A1, $0-18$ \\
\hline [A1A2], 22-44 & - & $\mathrm{A} 1 \mathrm{~A} 2,18-37$ \\
\hline [A2Bt], 44-65 & - & $\mathrm{A} 2 \mathrm{Bt}, 37-58$ \\
\hline$[\mathrm{Bt}], 65-106$ & - & Bt1, 58-92 \\
\hline$\left[\mathrm{BC}_{\mathrm{Ca}}\right], 106-145$ & - & Bt2, 92-117 \\
\hline Effervescence 106 & - & $\mathrm{BtC}_{\mathrm{Ca}}, 117-152$ \\
\hline & - & Effervescence 114 \\
\hline \multicolumn{3}{|c|}{ Podgornoe } \\
\hline $2030 \pm 50$ yrs. ago & $1150 \pm 110$ yrs. ago & Modern period \\
\hline$[\mathrm{A} 1], 0-26$ & {$[A 1], 0-16$} & A1, 0-19 \\
\hline [A1B], 26-44 & [A1A2], 16-29 & A1A2, 19-42 \\
\hline$[\mathrm{B}], 44-83$ & [A2A1Bth], 29-39 & $\mathrm{A} 2 \mathrm{Bt}, 42-61$ \\
\hline$[\mathrm{BC}], 83-107$ & [A2Bth], 39-54 & Bt1, 61-86 \\
\hline Effervescence 107 & {$[\mathrm{Bt} 1], 54-80$} & Bt2, 86-120 \\
\hline & {$[\mathrm{Bt} 2], 80-96$} & Effervescence 148 \\
\hline & Effervescence 140 & \\
\hline \multicolumn{3}{|c|}{ Borisovka } \\
\hline $2450 \pm 40$ yrs. ago & - & Modern period \\
\hline$[\mathrm{A} 1], 0-31$ & - & A1', 0-12 \\
\hline [A1B], 31-46 & - & A1", $12-28$ \\
\hline$\left[\mathrm{B}_{\mathrm{Ca}}\right], 46-93$ & - & $\mathrm{A} 1 \mathrm{~A} 2_{\mathrm{h}}, 28-45$ \\
\hline Effervescence 46 & - & $\mathrm{BtA} 2_{\mathrm{h}}, 45-65$ \\
\hline & - & Bt1, 65-96 \\
\hline & - & Bt2, 96-122 \\
\hline & - & Effervescence 122 \\
\hline \multicolumn{3}{|c|}{ Dmitrievka } \\
\hline $2800-2600$ yrs. ago & $1250 \mathrm{yrs}$. ago & Modern period \\
\hline$[\mathrm{A} 1], 0-31$ & [A1], $0-16$ & $\mathrm{Al}^{\prime}, 0-15$ \\
\hline [A1B], 31-39 & [A1A2], 16-40 & A1", $15-25$ \\
\hline$[B], 39-64$ & [A2Bt], 40-49 & A1A2, 25-36 \\
\hline$\left[\mathrm{BC}_{\mathrm{Ca}}\right], 64-82$ & {$[\mathrm{Bt}], 49-69$} & A2, 36-56 \\
\hline Effervescence 54 & {$[\mathrm{BtC}], 69-101$} & $\mathrm{~A} 2 \mathrm{Bt}, 56-66$ \\
\hline & Effervescence $>160$ & Bt1, 66-105 \\
\hline & & BtC, 105-140 \\
\hline & & Effervescence $>160$ \\
\hline \multicolumn{3}{|c|}{ Vodyanoe } \\
\hline $2450-2400$ yrs. ago & $1150-1050$ yrs. ago & Modern period \\
\hline$[\mathrm{A} 1], 0-42$ & [A1'], 0-27 & $\mathrm{A} 1^{\prime}, 0-23$ \\
\hline$[\mathrm{A} 1 \mathrm{~B}], 42-61$ & [A1"], 27-42 & A1", 23-45 \\
\hline$[\mathrm{B}], 61-99$ & [A1A2], 42-56 & A1A2, 45-63 \\
\hline \multirow[t]{3}{*}{ Effervescence 76} & [A2A1], 56-68 & $\mathrm{A} 2 \mathrm{Bt}, 63-81$ \\
\hline & {$[\mathrm{A} 2 \mathrm{Bt}], 68-84$} & Bt, $81-129$ \\
\hline & $\begin{array}{l}{[\mathrm{Bt}], 84-134} \\
\text { Effervescence }>160\end{array}$ & Effervescence $>160$ \\
\hline
\end{tabular}


Table 3. (Contd.)

\begin{tabular}{|c|c|c|}
\hline \multicolumn{3}{|c|}{ Symbols of soil horizons, characteristics depth intervals, and the depth of effervescence, $\mathrm{cm}$} \\
\hline \multicolumn{3}{|c|}{ Mokhnach } \\
\hline $2400-2300$ yrs. ago & 1250 & Modern period \\
\hline [A1], 0-27 & [A1], 0-27 & A1, $0-25$ \\
\hline [A1B], 27-40 & [A1Bt], 27-40 & A1Bt, 25-38 \\
\hline [B1], 40-72 & [B1t], 40-65 & A2Bt, 38-47 \\
\hline [B2], 72-100 & {$[\mathrm{B} 2 \mathrm{t}], 65-94$} & Bt $1,47-63$ \\
\hline$\left[\mathrm{BC}_{\mathrm{Ca}}\right], 100-130$ & {$[\mathrm{~B} 3 \mathrm{t}], 94-114$} & Bt2, 63-86 \\
\hline Effervescence 100 & {$\left[\mathrm{BC}_{\mathrm{Ca}}\right], 114-132$} & Bt3, 86-109 \\
\hline & Effervescence 132 & BtC, 109-145 \\
\hline & & Effervescence 180 \\
\hline \multicolumn{3}{|c|}{ Korobovy Khutora } \\
\hline $2450-2400$ yrs. ago & - & Modern period \\
\hline [A1], $0-23$ & - & A1, 0-39 \\
\hline [A1B], 23-49 & - & A1A2, 39-64 \\
\hline [B1], 49-69 & - & A2Bt, 64-86 \\
\hline [B2], 69-89 & - & Bt1, 86-111 \\
\hline$[\mathrm{BC}], 89-130$ & - & Bt2, 111-162 \\
\hline Effervescence 110 & & Bt3, 162-180 \\
\hline & - & Effervescence 220 \\
\hline & - & \\
\hline
\end{tabular}

The thickness of A1 horizons of buried soils was increased by $4 \mathrm{~cm}$ because of their compaction under ramparts as judged from bulk density values of the surface and buried soils. Dashes mean that the objects are missing.

features characteristic of podzolized chernozems in the studied profile of the buried paleosol include dark brown illuviation coatings on ped faces in the Bt horizon, its angular blocky structure, and bleached grayish skeletans on ped faces in the A1B horizon. They were formed due to the downward migration of substances under conditions of a relatively humid and cold microclimate under the forest canopy. Later, the features of chernozemic pedogenesis were superposed over this soil. As a result, the deep $(61 \mathrm{~cm})$ humus profile of chernozemic habitus was formed; dark organomineral coatings covered the dark brown coatings in the $\mathrm{B}$ and BC horizons; and the whitish carbonate coatings appeared in the layer of $54-130 \mathrm{~cm}$ from the surface of the buried soil (Fig. 3). The latter newly formed feature is genetically different from the typical illuviation coatings. The formation of carbonate coatings took place along the fissure network in the upward direction during the migration of soil solutions to the surface and their evaporation on the walls of the fissures and on aggregate surfaces. The thickness of these films on fissure walls increases downward the soil profile. Thus, we have identified two generations of coatings: carbonate coatings (films) were superposed over the earlier formed illuviation coatings. This change in the direction of the process could be caused by changes in the (micro)climatic conditions, i.e., by the replacement of the wet and cold climate by the warmer and drier cli- mate. This could only take place upon the substitution of meadow-steppe vegetation for forest vegetation.

In the lower part of the soil profile buried under the Scythian rampart, the features of the previous stage of pedogenesis (before the forest stage) were found: there were ancient mole-rat tunnels filled with the soil material differing in color from the surrounding soil mass.

These tunnels were formed before the dark brown illuviation coatings, because these coatings cover the walls of the tunnels and can be found in fissures crossing the tunnels (Fig. 3). The steppe stage of pedogenesis, whose features were clearly preserved in the paleosol of the Scythian time, could take place during the Subboreal period and earlier, which agrees with the existing notions about a drier climate of the foreststeppe zone in the Early and Middle Holocene in comparison with the Late Holocene [4, 25, 36].

The Mukhino site is found in Zadonsk district of Lipetsk oblast on a high flat promontory between two branches of a balka extending from the north to the south, where it is drained by the Snov River, $4 \mathrm{~km}$ upstream its junction with the Don River.

The Mukhino settlement was founded by representatives of the Scythian culture in the second century BC (the radiocarbon age of the charcoal comprised $2170 \pm 90$ yrs.). The rampart defended the settlement from the north, i.e., from the side of the interfluve with 
(a)

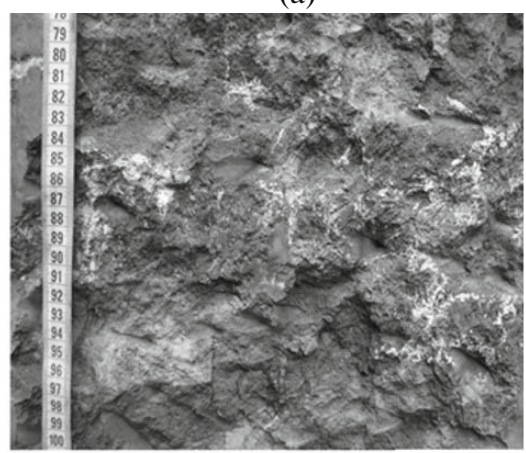

(b)

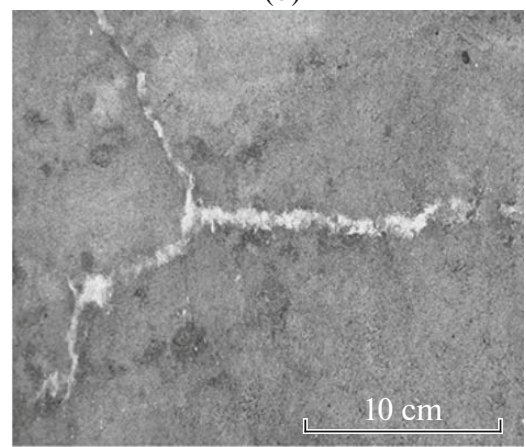

(c)



(d)

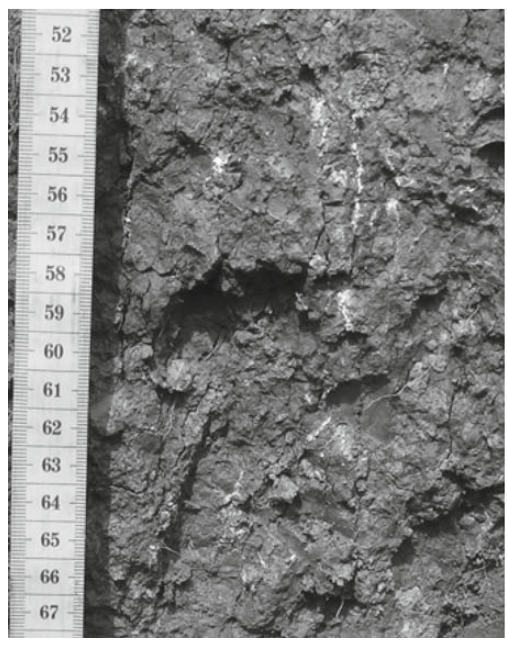

(e)

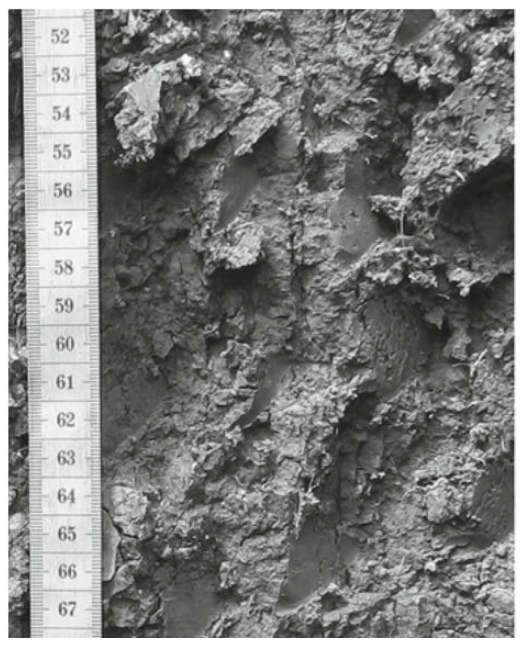

Fig. 3. Features of paleosols buried under ramparts of the Scythian time at the Vodyanoe site (a-c) and middle-profile horizons of the soil buried under the rampart and of the background surface soil at the Mukhino site (d, e). (a) Dark-brown illuviation coatings of the forest stage of pedogenesis and whitish carbonate coatings of the steppe stage of pedogenesis; (b) fissure network on a horizontal section in the lower part of the paleosol profile: fissure walls are covered by dark brown illuviation coatings, and the interfissure mass is covered by whitish carbonate coatings that appeared later than illuviation coatings; (c) the most ancient feature-paleotunnels of steppe mole-rats, the material of which is dissected by fissures with illuviation coatings; in turn, the latter are covered by carbonate coatings; (d) middle-profile horizon of the dark gray forest soil buried under the rampart with carbonate coatings overlying illuviation coatings on pore walls; and (e) illuviation coatings in the background gray forest soil without carbonates. 
minimum natural protection (Fig. 1). On the rampart, an underdeveloped gray forest soil was described. It had the following horizonation: $\mathrm{A} 1(0-7 \mathrm{~cm})-$ A1A2 $(7-20 \mathrm{~cm})-\mathrm{B}(20-55 \mathrm{~cm})-\mathrm{BC}(55-85 \mathrm{~cm})$. The $\mathrm{BC}$ horizon was characterized by the presence of a small amount of secondary carbonates in the material filling some light-colored tunnels of mole-rats.

The soil buried under the rampart had no carbonates in the surface horizon. The soil profile consisted of the following horizons.

[A1], 0-16 cm. Gray, crumb-granular, silty loamy, with empty earthworm paths.

[A1A2], 16-39 cm. Whitish gray, crumb-granular, silty loamy, with whitish skeletans on ped faces; coprolites and empty earthworm paths.

[A2Bt], 39-64 cm. Brownish gray with whitish tint; crumb-angular blocky (nutty), clay loamy, with whitish skeletans (bleached grains of quartz and feldspars) on the walls of fissures in the upper part of the horizon and with thin $(0.5-1 \mathrm{~mm})$ gray-brown glossy coatings on faces of angular blocky peds; in some loci, these coatings are covered by whitish carbonate coatings of up to $2 \mathrm{~mm}$ in thickness (Fig. 2). There are also grayish brown paleotunnels of mole rats with diffuse boundaries and more distinct brownish gray tunnels of mole rats of a younger age filled with loose soil material.

[Bt], 64-105 cm. Light brown, angular blocky to prismatic, with brown and chocolate-brown coatings on ped faces; along the fissures, these coatings are covered by thin whitish carbonate pseudomycelium; ancient gray-brown tunnels of mole rats are present together with younger tunnels of mole rats filled with brownish gray material.

$\left[\mathrm{BC}_{\mathrm{Ca}}\right], 105-145 \mathrm{~cm}$. Pale brown, blocky prismatic, clay loamy, with yellow brown illuviation coatings on ped faces covered by whitish pseudomycelium of carbonates; along the network of fissures, dirty yellow carbonate loess dolls with hard core and loose peripheral zone are found.

$\left[\mathrm{C}_{\mathrm{Ca}}\right], 145-160 \mathrm{~cm}$. Pale yellow to brownish yellow with ocherous tint, blocky prismatic, porous, calcareous silt loam; carbonates are present in the forms of whitish-yellow tubules, whitish efflorescence, and dirty yellow loess dolls.

The effervescence is seen along the fissures with visible concentrations of carbonates from the depth of $40 \mathrm{~cm}$; the entire soil mass effervesces from the depth of $105 \mathrm{~cm}$.

This soil can be classified as a silty loamy dark gray forest soil developed from the calcareous loesslike loam and subjected to the accumulation of carbonates (calcification).

The soil of the background surface was studied on a level interfluve, $15 \mathrm{~m}$ to the south from the rampart and $25 \mathrm{~m}$ from the studied buried soil. The distance from the studied pit to the nearest slope of the balka was about $30 \mathrm{~m}$.
A1, 0-18 cm. Gray, crumb-granular, silty loamy, with coprolites.

A1A2, 18-38 cm. Whitish light gray; blocky granular with elements of crumb structure; silty loamy, with whitish skeletans on ped faces; contains coprolites and empty earthworm paths.

A2Bt, 38-56 cm. Grayish brown with whitish tint; crumb-angular blocky, clay loamy, with skeletans along the network of fissures; angular blocky aggregates are covered by gray-brown glossy organomineral coatings; tunnels of mole-rats are filled with grayish brown material and have diffuse boundaries.

Bt1, 56-90 cm. Brown, angular blocky, clay loamy, with brown and gray brown glossy coatings on ped faces; few grayish brown tunnels of mole-rats.

Bt2, 90-110 cm. Light brown, angular blocky to blocky prismatic, clay loamy, with dark brown and chocolate-brown coatings on ped faces; few grayish brown tunnels of mole-rats.

$\mathrm{BtC}_{\mathrm{Ca}}, 110-150 \mathrm{~cm}$. Yellowish light brown, blocky prismatic, clay loamy, with brown and chocolatebrown glossy coatings on the faces of prismatic aggregates are seen down to the depth of $130 \mathrm{~cm}$; these coatings do not effervesce with $\mathrm{HCl}$, whereas the intraped mass displays distinct effervescence from the depth of $120 \mathrm{~cm}$. Secondary carbonates are represented by whitish yellow tubules and by dirty yellow loess dolls along large vertical fissures.

$\mathrm{C}_{\mathrm{Ca}}, 150-170 \mathrm{~cm}$. Brownish yellow, coarse blocky porous silty loam; dirty yellow carbonate tubules; loess dolls along vertical fissures.

The soil slightly effervesces from the depth of $120 \mathrm{~cm}$; in the deeper horizons, the effervescence is more pronounced.

This soil is identified as a typical silty loamy gray forest soil developed from calcareous loesslike loam.

The morphology of the studied soils indicates that the period of construction of the rampart was marked by climatic aridization resulting in progradation of the gray forest soil into the chernozem under herbaceous meadow-steppe vegetation. This is seen from the appearance of carbonate concentrations along the fissures in the $[\mathrm{A} 2 \mathrm{Bt}],[\mathrm{Bt}]$, and $\left[\mathrm{BC}_{\mathrm{Ca}}\right]$ horizons in the form of carbonate coatings and pseudomycelium covering brown glossy illuviation coatings formed during the previous forest stage of the soil development. In the soil profile buried under the rampart, two generations of mole-rat tunnels can be distinguished: ancient paleotunnels with diffuse boundaries reflect the Middle Holocene stage of steppe pedogenesis, whereas younger and more distinct tunnels could be formed under steppe vegetation during the Scythian time, not long before the rampart construction and the soil burying. These tunnels are filled with loose humified soil material. Ancient tunnels are less distinct, and the structure of the material filling them is analogous to the structure of the enclosing soil mass, i.e., it is angu- 
Table 4. Morphometric characteristics of chernozems of the Early Iron Age studied in the central forest-steppe region under different geomorphic conditions

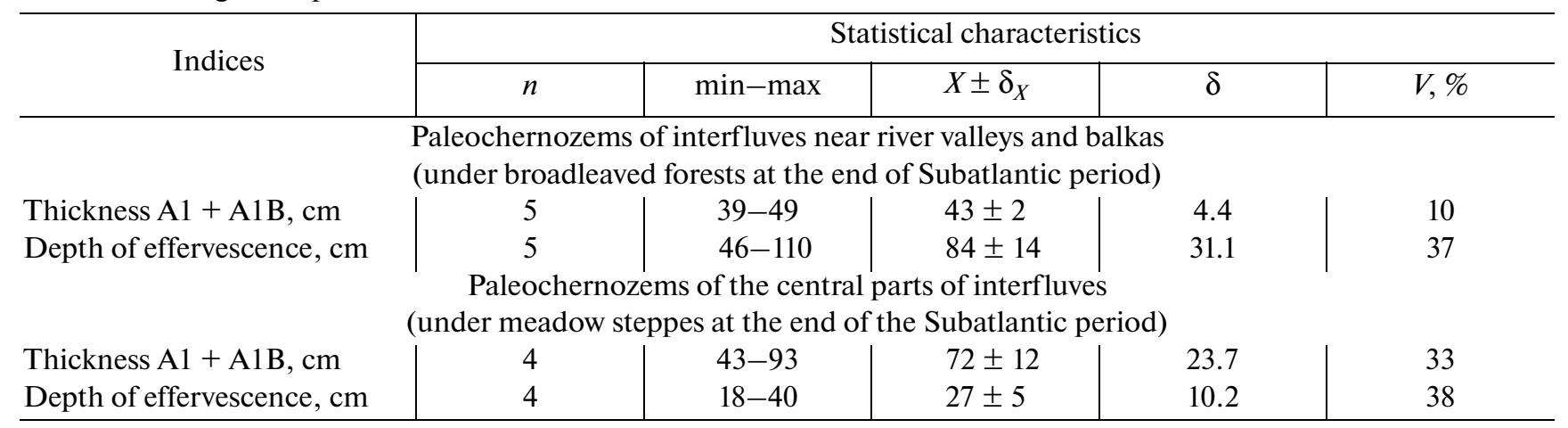

lar blocky in the Bt horizon. This means that the initially loose filling of the ancient tunnels was strongly transformed by pedogenetic processes and acquired the structure of the enclosing horizons.

The appearance of steppe vegetation in place of former forests during the Scythian-Sarmatian period of climatic aridization was also recorded in the properties of paleosols buried under the ramparts at the Verkhnee Kazachie and Podgornoe sites. The thickness of the ramparts atop of these paleosols reaches $115-175 \mathrm{~cm}$. The paleosol profiles contain the accumulations of secondary carbonates along the fissures; these carbonates were superposed over the earlier formed illuviation coatings in the middle part of the soil profiles. The upper parts of the profiles did not contain carbonates. As well as at the Mukhino site, they contained "fresh" tunnels of mole-rats that could be formed under steppe vegetation not long before the construction of the ramparts.

The paleosol buried under the rampart at the Mukhino site was identified as a dark gray forest soil. The surface soil developed on the interfluve was identified as a gray forest soil. The features of steppe pedogenesis in its profile are preserved in the form of paleotunnels of steppe mole-rats. The initially humified material filling these tunnels has acquired very pale color, and their boundaries have become more diffuse in comparison with analogous tunnels in the buried paleosol. The eluvial-illuvial differentiation of the background soil is more pronounced than that of the buried paleosol. In particular, the background soil has a distinct pale grayish A1A2 horizon and a thicker illuvial layer with the Bt 1 and $\mathrm{Bt} 2$ subhorizons, in which illuviation coatings have become darker and more pronounced in the profile.

These facts point to the major direction of the soil evolution under forest vegetation in the first and second millennia $\mathrm{AD}$. It is probable that the steppe stage of pedogenesis was replaced by the forest stage several centuries after the rampart construction. This change took place after the end of the phase of aridization in the third-fourth centuries AD [5, 36]. Thus, the soil on the rampart developed under steppe vegetation for about $300-350$ years. In the modern soil profile, the steppe phase of pedogenesis is reflected by numerous tunnels of steppe mole-rats in the thickness of the rampart. The pedogenesis on the rampart followed the chernozemic pattern for about 300-350 years; about 1700-1650 years ago, the chernozemic pedogenesis was replaced by the forest pedogenesis.

The specificity of the profiles of chernozems developed during the Early Iron Age and studied on the now forested parts of the interfluves near the river valleys becomes evident upon their comparison with the chernozems of the same age buried under Scythian kurgans in central parts of the interfluves under steppe (Table 3). Data on the morphometric characteristics of typical chernozems of the Scythian time (26002200 years ago) were obtained in Graivoronovo, Borisov, and Belgorod districts of Belgorod oblast and in Ostrogozh district of Voronezh oblast and summarized in [35]. Chernozems buried under Scythian kurgans in the central parts of interfluves have a silty loamy texture. Thus, they could be compared with the paleosols of the same texture formed in the peripheral parts of interfluves (Table 3). The sandy loamy paleochernozem under the rampart of the Vodyanoe settlement was excluded from the analysis.

As seen from Table 4, morphometric characteristics of paleochernozems of the Early Iron Age formed in the peripheral (near river valleys) and central parts of level interfluves are different, and this difference is statistically significant. Near the valleys, the chernozems of the Early Iron Age had thinner humus layers and deeper boundary of effervescence in comparison with their analogues in central parts of the interfluves. This fact can be explained by the incomplete development of the profiles of automorphic chernozems in the Early, Middle, and Late Holocene (until the establishment of forest vegetation (1600-1700 years ago) and the substitution of forest pedogenesis for steppe pedogenesis. At present, gray forest soils are developed in these areas. We suppose that "underdeveloped" profiles of automorphic chernozems on the interfluves near river valleys are explained by repeated alternation of forest and steppe vegetation in these geomorphic 
Humidization phase

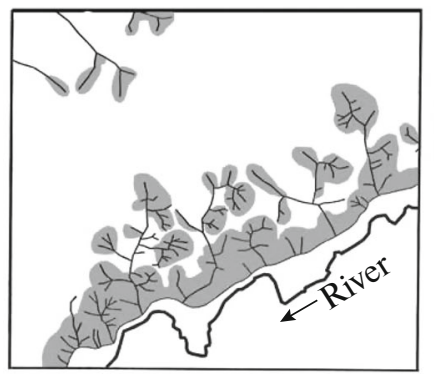

Aridization phase

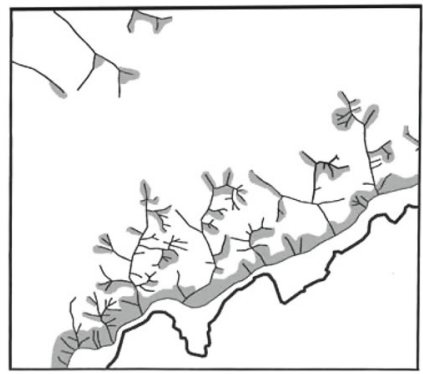

Areas with different variants of



evolution of gray forest soils:

Fig. 4. Hypothetic scheme of changes in the area of forests in the southern part of forest-steppe on the Central Russian Upland in the Holocene and the related variants of evolution of gray forest soils from chernozems. The phases of humidization and aridization of the climate and the related dynamics of forests repeatedly took place in the Holocene (two left figures). The period of stable moistening with the unidirectional advance of forest vegetation and transformation of chernozems into gray forest soils corresponds to the last 1600-1700 years (two right figures). Variants of soil evolution: (I) pulsating evolution typical of interfluve areas near balkas and river valleys and (II) continuous evolution typical of the central parts of the interfluves.

positions during the Holocene. These changes could hamper the development of deep humus profiles typical of the zonal chernozems in the central parts of interfluves. They were caused by the climatic dynamics in the Holocene. We suppose that the response of ecosystems near river valleys and balkas to climate changes was faster than the response of steppe ecosystems in central parts of the interfluves. During short periods of climatic humidization, the advance of forest vegetation toward central parts of steppe interfluves was slow because of their remote position from forests localized in river valleys and balkas even in dry periods of the Holocene [14, 26].

We suppose that the Scythian-Sarmatian period of climatic aridization that separated two more humid periods with forest pedogenesis can be considered a model of climate changes in the earlier periods of the Holocene. According to available data, the phases of humidization of the climate in the forest-steppe region could take place 9000-8300, 8000-7200, 6600-6200, 5600-5100, $4800-4300$, and $4000-3500$ years ago [26, 28].

It can also be supposed that the patterns of soil evolution in response to climate changes in the studied region were different. At least two their variants can be distinguished for the gray forest soils in the southern part of the forest-steppe zone on the Central Russian Upland.

(1) Soil evolution in the peripheral parts of the interfluves near balkas and river valleys was characterized by repeated alternation of steppe and forest stages of pedogenesis with the forest pedogenesis established after the Scythian-Sarmatian period of climate aridization that ended 1600-1700 years ago. We suggest that this evolutionary pattern can be referred to as the pulsating evolution of gray forest soils from chernozems.

(2) Soil evolution in the central parts of the interfluves that are under forest vegetation at present was characterized by the continuous steppe pedogenesis in the major part of the Holocene; after the ScythianSarmatian period of climatic aridization, it was replaced by the forest pedogenesis. The frontal advance of forest vegetation over steppe vegetation in the central parts of the interfluves lagged behind this process near the river valleys, and short-term periods of climatic humidization in the Early and Middle Holocene did not lead to the substitution of forest pedogenesis for steppe pedogenesis. In this case, we deal with the continuous progressive evolution of chernozems under steppe vegetation, which was replaced by the Late Holocene stage of forest pedogenesis and transformation of the former chernozems into gray forest soils.

The schematic patterns of these two variants of soil evolution are illustrated by Fig. 4 .

\section{CONCLUSIONS}

At the beginning of the Subatlantic period of the Holocene, the areas of gray forest soils under broadleaved forests existed in the northern part of the foreststeppe zone of the Central Russian Upland in the peripheral parts of interfluves. In its southern part, under similar geomorphic conditions, chernozems continued to develop under herbaceous steppe vegetation, or were at the initial stage of their transformation under forest vegetation.

In the southern part of the forest-steppe zone (approximately to the south of Lipetsk), automorphic gray forest soils as the zonal type of forest-steppe pedogenesis originated from the former chernozems under the impact of the Late Holocene humidization of the climate and the advance of forest vegetation over steppe. The major stage of the evolutionary transformation of chernozems into gray forest soils lasts for about 1600-1700 years after the end of the Scythian- 
Sarmatian phase of climate aridization in the Subatlantic period. Further to the south, closer to the steppe zone, the rates of the evolutionary transformation of chernozems into gray forest soils were slower than those in the colder northern part of the region.

The Scythian-Sarmatian phase of climatic aridization and propagation of steppe vegetation was reflected in the properties of the soils buried under ramparts around ancient settlements of the Early Iron Age (2400-2300 years ago) on the interfluves near the valleys. Illuviation coatings and bleached skeletans in the soil profiles reflect the previous stage of forest pedogenesis, whereas carbonate coatings atop of illuviation coatings, carbonate pseudomycelium, and numerous tunnels of steppe mole-rats reflect the short-term phase of steppe pedogenesis; steppe vegetation returned to the sites earlier covered by forests.

The Scythian-Sarmatian phase of climatic aridization can (the 5 th century BC-3rd century AD) can be considered a model for short-term dynamics of the climate, vegetation, and soils in the areas with the dense drainage network characterized by the simultaneous presence of forest vegetation in the depressions and steppe vegetation on the elevated elements of topography.

Peripheral parts of the interfluves near river valleys and balkas are characterized by the pulsating type of the evolution of gray forest soils with multiple alternation of the stages of steppe and forest pedogenesis against the background trend of the formation of steppe chernozems in the Middle Holocene and gray forest soils in the Late Holocene. Under the impact of these frequent changes in the character of pedogenesis, the chernozems developed there by the beginning of the Subatlantic period were thinner and more leached from carbonates than chernozems in the central parts of the interfluves that developed under steppe communities for a longer time. After the Scythian-Sarmatian period of climatic aridization, relatively thin chernozems in the peripheral parts of the interfluves have been transformed into modern gray and dark gray forest soils under the impact of forest pedogenesis.

In the central parts of the interfluves far from river valleys, the pattern of soil evolution had a more continuous character. By the beginning of the Subatlantic period, these areas were occupied by well-developed chernozems with deep humus horizons. After the end of the Scythian-Sarmatian phase of climatic aridization, the advance of forest vegetation over these territories took place later than that near the river valleys, because some time was required for the frontal "movement" of forest vegetation from its source areas in the valleys toward central parts of the interfluves.

\section{ACKNOWLEDGMENTS}

This study was supported by the Russian Science Foundation, project no. 14-17-00171.

\section{REFERENCES}

1. A. L. Aleksandrovskii, "Environment of the Upper Don region in the second half of the Holocene according to analysis of paleosoils of the towns of Early Iron Age," in Archeological Monuments of the Upper Don Region in the Second Half of the First Century BC (Voronezh State Univ., Voronezh, 1998), pp. 194-199.

2. A. L. Aleksandrovskii, "Soil evolution in Eastern Europe at the boundary between forest and steppe," in Natural and Anthropogenic Evolution of Soils (Pushchino, 1988), pp. 82-94.

3. A. L. Aleksandrovskii and E. I. Aleksandrovskaya, Soil Evolution and the Environment (Nauka, Moscow, 2005) [in Russian].

4. A. L. Aleksandrovskii and A. A. Gol'eva, "Paleoecology of ancient man according to the data of interdisciplinary studies of soils of archeological sites in the Upper Don region," in Archeological Monuments of the Forest-Steppe Don Region (Lipetsk, 1996), No. 1, pp. 176-183.

5. A. L. Aleksandrovskii, Yu. G. Chendev, and M. A. Trubitsyn, "Paleosol indicators of the dynamics of ecological conditions in the Central forest-steppe in the Late Holocene," Izv. Ross. Akad. Nauk, Ser. Geogr., No. 6, 87-99 (2011).

6. E. A. Afanas'eva, Chernozems of the Central Russian Upland (Nauka, Moscow, 1966) [in Russian].

7. B. P. Akhtyrtsev, "The history of development and anthropogenic evolution of gray forest-steppe soils," Vestn. Voronezh. Gos. Univ., Ser. 2, No. 2, 11-19 (1996).

8. B. P. Akhtyrtsev, Gray Forest Soils of Central Russia (Voronezh State Univ., Voronezh, 1979) [in Russian].

9. B. P. Akhtyrtsev and A. B. Akhtyrtsev, "Evolution of soils of the Central Russian forest-steppe in the Holocene," in Evolution and Age of Soils of the Soviet Union (Pushchino, 1986), pp. 163-173.

10. N. B. Vernander, "Origin and properties of gray forest soils of the western part of Ukrainian SSR," in Study of Soil Genesis (Academy of Sciences of Soviet Union, Moscow, 1963), pp. 164-183.

11. Genesis, Evolution, and Typology of Soil-Forming Minerals in the Northeastern Ukraine (Kharkov, 1988) [in Russian].

12. A. N. Gennadiev, "Analysis of soil-forming processes by the method of chronological sequences in the Elbrus area," Pochvovedenie, No. 12, 33-43 (1978).

13. A. N. Gennadiev, Time and Soils: Models of Development (Moscow State Univ., Moscow, 1990) [in Russian].

14. M. I. Dergacheva, Archeological Soil Sciences (Siberian Branch, Russian Academy of Sciences, Novosibirsk, 1997) [in Russian].

15. I. V. Ivanov and A. L. Aleksandrovski1, "Methods of the study of soil evolution," Pochvovedenie, No. 1, 112-121 (1987).

16. V. A. Klimanov and T. A. Serebryannaya, "Dynamics of vegetation and climate of the Central Russian Upland in the Holocene," Izv. Akad. Nauk SSSR, Ser. Geogr., No. 2, 26-37 (1986).

17. S. I. Korzhinskii, "Northern boundary of chernozemic steppe region in the eastern part of European Russia in 
botanical-geographical and soil aspects," Tr. O-va Estestvoispyt. Imper. Kazan. Univ., 22 (6), (1891).

18. P. A. Kostychev, "Relationship between soils and some plant communities," VIII Congress of Russian Naturalists and Physicians (St. Petersburg, 1890), pp. 37-60.

19. F. N. Mil'kov, "Hypothesis of subboreal xerothermic epoch and shift of landscape zones according to archeological data," Tr. Voronezh. Gos. Univ. 42, 38-66 (1957).

20. F. N. Mil'kov, Physical Geography: Theory of Landscape and Geographical Zonality (Voronezh State Univ., Voronezh, 1986) [in Russian].

21. I. A. Pavlenko, "Forest-steppe soils of mountain oak forests on the right bank of the Vorskla River and their origin," in Geography and Genesis of Forest Soils of European Part of Soviet Union (Academy of Sciences of Soviet Union, Moscow, 1955), pp. 191-287.

22. V. V. Ponomareva and T. A. Plotnikova, Humus and Soil Formation (Nauka, Leningrad, 1980) [in Russian].

23. Nature of Ukrainian SSR. Soils (Naukova Dumka, Kiev, 1986) [in Russian].

24. I. A. Raskatov, Geomorphology and Neotectonics of the Territory of Voronezh Anteclise (Voronezh State Univ., Voronezh, 1969) [in Russian].

25. T. A. Serebryannaya, "Dynamics of the boundaries of Central forest-steppe in the Holocene," Conference in Memoriam of Academician V.N. Sukachev "Century Dynamics of Biogeocenosises” (Nauka, Moscow, 1992), pp. 54-71.

26. E. A. Spiridonova, Evolution of Vegetation Cover in the Don River Basin in the Upper Pleistocene-Holocene (Nauka, Moscow, 1991) [in Russian].

27. G. P. Surmach, "Distribution of plant communities and gray forest soils and forest-steppe chernozems as related to specific lithological structure of loess sediments," Pochvovedenie, No. 1, 7-16 (1987).
28. S. A. Sycheva and O. A. Chichagova, "Soils and cultural layer of Scythian site of Pereverzevo-1 ancient settlement (the Seim River basin, Kursk oblast)," in Handbook for the Analysis of Paleoecology of Cultural Layers of Ancient Settlements: Experimental Studies (Institute of Archeology, Russian Academy of Sciences, Moscow, 2000), pp. 62-70.

29. S. A. Sycheva, O. A. Chichagova, E. K. Daineko, et al., "Stages of erosion development on the Central Russian Upland in the Holocene," Geomorfologiya, No. 3, $12-$ 21 (1998).

30. V. I. Taliev, "Man as a botanical and geographical factor,” Nauch. Obozr., No. 11, 42-61 (1902).

31. T. V. Tursina, "Approaches to the study of the lithological homogeneity of soil profiles and soil polygenesis," Eurasian Soil Sci. 45 (5), 472-487 (2012).

32. I. V. Tyurin, "Genesis and classification of foreststeppe and "forest" soils," Uch. Zap. Kazan. Univ., Nos. 3-4, 429-462 (1930).

33. O. S. Khokhlova, A. A. Khokhlov, N. L. Morgunova, and A. A. Yustus, "Short chronosequences of paleosols from the Skvortsovka kurgans in the Buzuluk River valley of Orenburg oblast," Eurasian Soil Sci. 43 (9), 965976 (2010).

34. Yu. G. Chendev, Natural Evolution of Soils in the Central Forest-Steppe in the Holocene (Belgorod State Univ., Belgorod, 2004) [in Russian].

35. Yu. G. Chendev, Evolution of Forest-Steppe Soils of the Central Russian Upland in the Holocene (GEOS, Moscow, 2008) [in Russian].

36. Yu. G. Chendev and A. L. Aleksandrovskii, "Soils and environment in the Voronezh River basin in the second half of the Holocene," Eurasian Soil Sci. 35 (4), 341348 (2002).

Translated by D. Konyushkov 